\title{
SANATTA NEON IŞIKLARI
}

Figen GiRGiN ${ }^{1}$

Atıf/C: Girgin, F. (2018). Sanatta neon 1ş1kları. Hitit Üniversitesi Sosyal Bilimler Enstitüsü Dergisi, 11(3), 2315-2329. doi: 10.17218/hititsosbil.425113

Özet: 19.yy sonlarında keşfedilen neonu, 20.yy başlarında Fransız kimyager ve fizikçi Georges Claude neon tüpleri olarak geliştirir. Başlangıçta reklam ya da tabela olarak kullanım alanına sahip olan neon 1ş1kları -günümüzde hâlâ bu işlevini de sürdüren- 1930'larda László Moholy-Nagy'nın dikkatini çeker ve sanatçı, fotoğraflarında neon ışıklarına yer verir. Böylelikle ışığın renk ile yarattığı soyut titreşimi ile neon 1şıkları, iki boyutlu yüzey üzerine aktarımı ile sanat alanına girer. Daha sonraları mekânın belli bir bölümünü ya da tamamını; yazı, renk veya sadece biçimi ile ele geçirir. Bazen bir resme, fotoğrafa, heykele, objeye ya da mekânın genel formuna eşlik eder. Ya da bir heykelin dış çizgilerini oluşturur ve ona boyut kazandırır. Bazen ise renk ve 1şıkla yazılan metin, konuşma ve yazma edinimini başlatır, görme edinimini başka bir boyuta taşır. Bir mekânın duvarı, tavanı, zemininde ya da dişında, görüntünün yerine geçer ve izleyicinin onu hayal etmesine olanak sağlar. Bu fosforlu 1şık, izleyiciyi etkisi altına alır. Parlaklığı çekicidir, cezbedicidir. Betimsel tarama modelli olan bu araştırmada; neon 1şıkları ile çalışan bazı sanatçıların yapitlarına yer verilmiştir. Bu yapıtlar aracılığıyla: "Neon 1şıkları bir yapıtın içeriğine nasıl katkı sağlar? Neon 1şıkları ile form oluşturulabilir mi? Neon 1şıkları bir yapıtın sadece malzemesi midir? Neon 1şıkları sanatta nasıl kullanılır?” sorularına cevap aranmıştır.

Anahtar Kelimeler: Neon ışıkları, Çağdaş sanat, Işık, Sanat, Mekân

\section{Neon Lights in the Art}

Citation/(): Girgin, F. (2018). Neon lights in the art. Hitit University Journal of Social Sciences Institute, 11(3), 2315-2329. doi: 10.17218/hititsosbil.425113

Abstract: Neon, discovered in the late 19th century, was developed by chemist and physicist Georges Claude as French neon tubes in the early 20th century. Neon lights, initially using as advertising or signage -which is also used today with this function- caught the attention of László Moholy-Nagy in the 1930s and the artist used neon lights in his photographs. Thus, with the abstract vibrations created by the light with color, neon lights enter the field of art by transferring them onto a twodimensional surface. Next, a certain part or all of the space; it captures with text, color, or just form. Sometimes it accompanies to a painting, a photo, a sculpture, an object, or a general form of space. Or it creates the outlines of a sculpture and adds dimension to it. Sometimes the text, written in color and light, initiates the acquisition of speech and writing, bringing vision acquisition to another dimension. It replaces the image the wall, the ceiling of a space, on the ground or outside and allows the viewer to imagine. This phosphorescent light affects the spectator. It's brightness is attractive. In this research, which is a descriptive scanning model, artworks of some artists using neon lights were mentioned. It was tried to answer some questions through these artworks: "How do the neon lights contribute to the content of an artwork? Can the form be created with neon lights? Neon lights are just a material of an artwork? How are neon lights used in the art? "

Keywords: Neon lights, Contemporary art, Light, Art, Space

Makale Geliș Tarihi: 18.05.2018

Makale Kabul Tarihi: 12.12.2018

Bu çalışma, 9-11 Mart 2018 tarihleri arasında Mardin'de düzenlenen 1.Uluslararası İksad Sosyal Bilimler Kongresi adlı etkinlikte sözlü bildiri olarak sunulmuş ve özeti kongre bildiri özet kitabında basılmış bildirinin tamamlanmış halidir.

${ }^{1}$ Arş. Gör. Dr., Trakya Üniversitesi, Eğitim Fakültesi, Güzel Sanatlar Eğitimi Bölümü, fffff_g@hotmail.com, http://orcid.org/0000-0002-5747-6769 


\section{GİRIŞ̧}

Doğal ve yapay olarak ikiye ayrılan 1şık kaynağını sanat alıcısının 20.yy’a kadar, bazen varlığı ile bazen ise yansıması ile tanımlayabildiği, ışı̆̆ın geliş açısını ise yine gölge ve resimde yer alan öğelerde değişen renk değerleri ile algılayabildiği bir durum söz konusuydu. Ancak 1şı̆̆ın bu pasifliği, 20.yy'ın ilk çeyreğinden sonra aktif ve eseri harekete geçirici hale dönüşür. Bu dönemlerde sabit bir elektrik kaynağının erişilebilir olması insanların yaşamlarını değiştirir ve aynı zamanda sanatta da teknoloji ile bütünleşen bir bakış açısına yol açar. Resimde bir öğe olarak yer almadığı sürece, ön planda değil; gizli kahraman olarak yer alan 1şık, artık izleyicisanat eseri ve mekân arasında arabulucu rolü üstlenir ve ön plandadır. Sadece eserin malzemesi değildir. Çă̆daş sanatçılar, ışığın yansıtıcı ve renk özelliklerini kullanmanın yanı sıra onu sanatsal estetiklerini sunmanın, eserin izleyici ile etkileşime geçmesinin bir yolu olarak görürler. Bazen yazı ile birliktelik içinde olan neon 1şıkları, kodlanmış metin ya da kelimenin izleyiciye dolaylı bir aktarım sunma ya da onları deneyime sürükleme aşamasında oldukça etkilidir. Işık, özellikle de karanlıktaki 1şık; insanı çoğunlukla kendine çekme potansiyelinde olan büyülü bir etkiye sahiptir. Bu anlamda neon 1şıkları ister mekânla bütünleşen türden olsun, ister heykelle isterse de metin ile sunulmuş olsun, izleyiciyi önce kendine çekme sonra da o çalışma ile etkileşime sokması bakımından oldukça etkilidir. Neon 1şı̆̆ını sadece bir malzeme olarak ya da yapıtın pasif bir öğesi olarak görmeyen, izleyici ile yapıtı etkileşime sokma bakımından öne çıkan bazı sanatçıların eserlerine yer verilerek: "Neon 1şıkları bir yapıtın içeriğine nasıl katkı sağlar? Neon 1şıkları ile form oluşturulabilir mi? Neon 1şıkları bir yapıtın sadece malzemesi midir? Neon 1şıkları sanatta nasıl kullanılır?” sorularına cevap aranmıştır.

\subsection{László Moholy-Nagy}

Işık ve hareket üzerine birçok araştırma yapan László Moholy-Nagy, sanat ve teknolojiyi birleştiren yeni bir vizyonun da öncülerindendir. 1921'de 1şığa duyarlı kağıtlar ya da fotoğraf levhalarının arasına yerleştirdiği nesneleri, daha güçlü bir 1şık kaynağına maruz bırakarak elde ettiği hayalete benzeyen deneysel çalışmalarda, 1şık-hareket ve mekânı dahil ederek yeni bir ilişki ağı yaratır. Fotogram (kamerasız fotoğraf) adını verdiği bu keşfi, 'Işık Mekân Modülatörü' adlı kinetik heykeli icat etmesini sağlayacaktır. Sanatçı bu işinin arkasındaki kavramı şu sözleri ile açıklar:

"Zengin aydınlatma efektleri düzenlenebilir 1şık vasıtasıyla üretilebilir. Elektrik hareketi değişim olmaksızın tekrarlanabilen önceden hesaplanmış farklı hareketleri fark etmemizi mümkün kılar. Mevcut ilişkilerine göre, 1 şık ve hareket yeniden yaratı öğeleri haline gelir. Barok çağındaki çeşmeler, su oyunları ve sahne, 1ş1k görüntüleri ve mekanik elektrikli kinetik görüntülerle yaratıcı bir şekilde yenilenebilir" (Kawamura Memorical Dic Museum of Art, t.y.).

$\mathrm{Bu}$ modülatör, makinenin sanatsal estetiğine ilişkin bir örnek teşkil etmenin yanı sıra, değişen ses ve 1 şı efektleri ile izleyiciyi çevrelemekte ve onların sahnedeki eyleme katılmalarına katkı sağlamaktadır (Farthing, 2012, s. 419). 


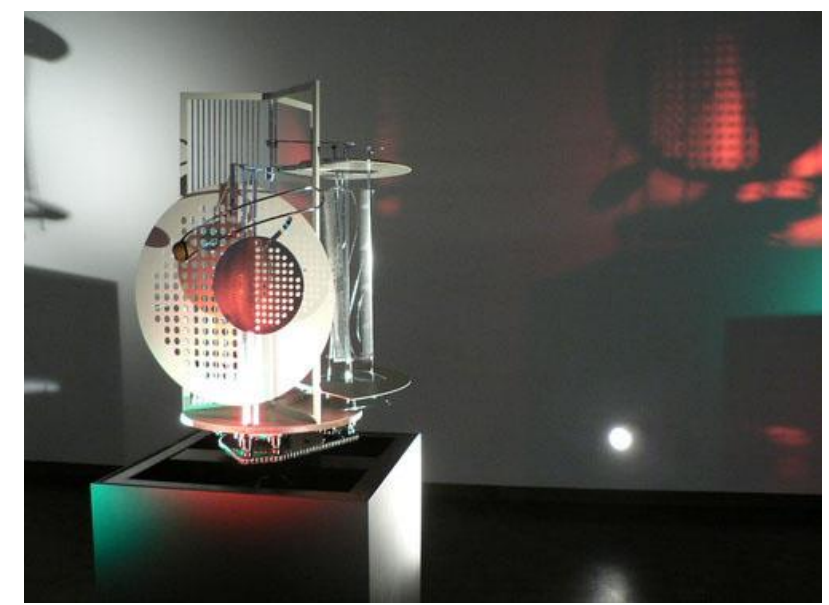

Resim 1. László Moholy-Nagy, Işık-Mekân Modülatörü, Alüminyum, çelik, nikel kaplı pirinç, diğer metaller, plastik, ahşap ve elektrik motoru, 151,1 x 69,9 x 69,9 cm

$\mathrm{Bu}$ aydınlatma donanımı hem 1şık oyunları hem de hareketi görmek için kullanılan bir cihazdır. Model, ön tarafında dairesel açılmanın olduğu 120x120 cm ebatlarında küp benzeri bir kutudan oluşur. Panelin arkasında açıklığın etrafına sarı, kırmızı ve beyaz renklerde elektrik ampulleri monte edilmiştir. Ön tarafa paralel, gövdenin içine yerleştirilen bir ikinci panel vardır. Bu panel de farklı renklerde elektrik ampulleri monte edilmiş bir açıklık taşır. Önceden belirlenmiş plana göre bireysel olan ampuller farklı noktalarda parlar. Onlar kapalı kutunun arka duvarında en iyi gölge oluşumunu sağlamak için yarı şeffaf, kısmen şeffaf ve kısmen perdahlanmış malzemelerden oluşan sürekli hareket eden mekanizmayı aydınlatırlar. Gösteri, karanlık bir ortamda gerçekleştirildiğinde kutunun arka duvarı çıkarılabilir ve renk ve gölge projeksiyonu kutunun arkasında seçilen herhangi boyutta bir ekranda gösterilebilir. Mekanizma, dairesel bir platform ile desteklenmektedir. Bölme duvarları, şeffaf selofan ve dikey çubuklardan oluşan metal bir duvardan yapılmıştır. Çerçevedeki üç bölgenin her biri, farklı ve eğlenceli bir hareketi sağlamakla görevlidir (Moholy-Nagy, t.y.).

Moholy-Nagy'nin 1şık ile ilgili bu araştırmalarının sabit bir elektrik kaynağına erişimin olduğu döneme denk gelmesi, bunun insanlar üzerindeki etkisini de gözler önüne serer. Onun 1ş1k ve hareket üzerine yaptığı bu deneysel araştırmalar, neon 1şıkları ile yapılan çalışmaların ve medya sanatının da ilk tomurcukları olarak görülebilir.

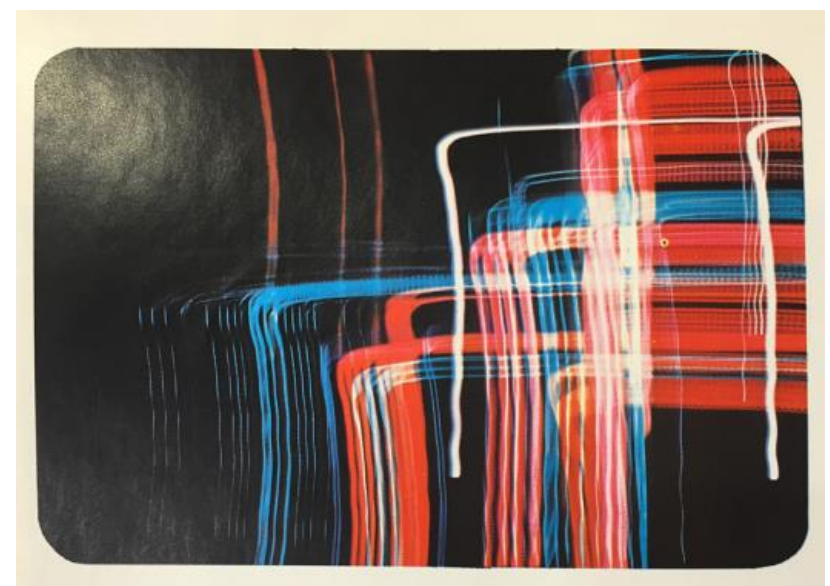

Resim 2. László Moholy-Nagy, Neon Işıkları Chicago, 1939, Renkli fotoğraf 
Işıkla yaptığı bu üç boyutlu denemenin yanı sıra sanatçı, 1920'lerin başında Berlin'de yaşadığı dönemde siyah-beyaz olarak başladığı şehir görüntülerine, göç ettiği Chicago'da devam eder. Tamamen insandan ve her türlü nesneden arındırılmış, sadece 1şıklardan oluşan bir şehir görüntüsü yaratır. Randolph ve State Caddelerinin köşelerinde gece boyunca zamanının çoğunu geçirir ve trafik lambaları, sokak ışıkları, restoran, hotel ve gece kulüplerinin neon ışıklarını inceler. Şehirdeki renkli kaosu kayda alır. Şehrin coşkulu ve kaotik görüntüsü, 1şıkların titreşimi ile soyutluğa bürünür (Ribbat, 2013, s. 60). Adeta şehir 1şıklarla sarhoş olmuş gibidir. Aslında bu seride insanların yoğun olduğu bar, restoran, hotel gibi birçok mekân yer alır. Ama biz izleyiciler olarak, sadece soyut renk titreşimlerini görürüz. Çünkü o, daha önce de belirtildiği gibi bu panoramik şehir görüntülerinde yalnızca ışığa bakar ve bize, ışığı aktarmayı tercih eder.

\subsection{Lucio Fontana}

Lucio Fontana ise metafizik bir alana girerek nesnenin ötesine geçmeyi amaçlar. Bu anlamda maddi nesnenin canlı gerçekliğini daha içkin biçimde gerçek ama aynı zamanda maddi olmayan uzamsal bir yerleştirme ortaya çıkarmak için kullanır. Düşüncelerini belirli bir uzama yaymayı denediği neon enstalasyonları da onun bu sanatsal yaratılarının en güzel örnekleri arasındadır (Fineberg, 2014, s.145).

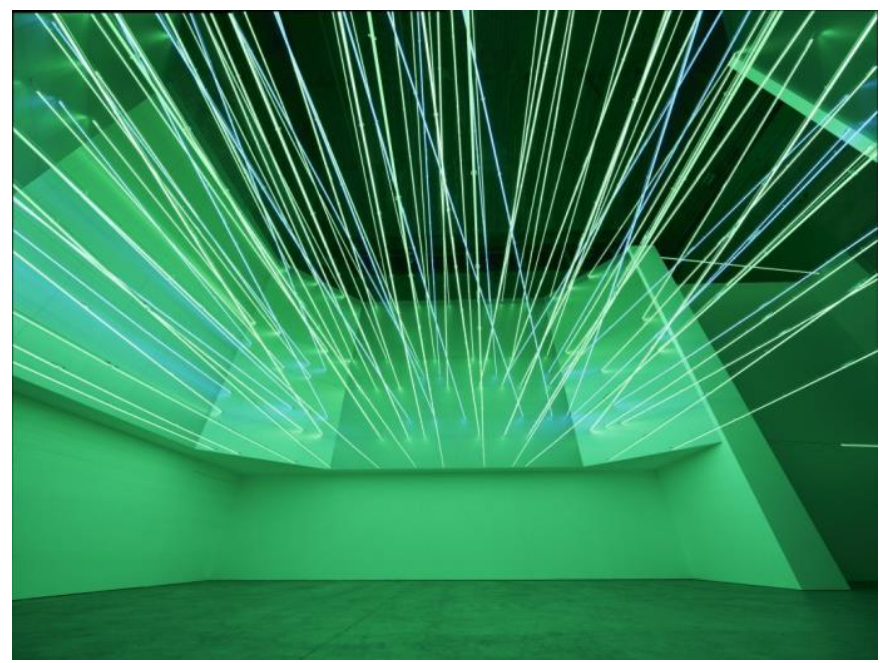

Resim 3. Lucio Fontana, Enerji Kaynaklar1, 1961, Enstalasyon, Yeniden sergilenmesi: Pirelli HangarBicocca, Milano, 2017

Zaman ve mekâna bağlı yeni bir temsil biçimi arayışında olan Fontana, neon enstalasyonlarında, öncelikle resim ve heykeldeki klasik malzemeleri bir kenara bırakarak, ışık ve yapay formları yaratmak için modern teknolojiden faydalanır. Yüzeyde açtığı kesikler ve delikler ile daha çok bilinen sanatçı, her daim yenilikçi ve deneysel bir yaklaşım sergilemiştir. Neon 1şıları, onun klasik malzemeyi terk etmesinde önemli bir yer işgal eder. Bu işıklar, ultraviolet ışınları ile birlikte sanatçıya istediği uzamsal çevreyi yaratma firsatı tanır.

Fontana'nın belirttiği gibi: "Uzamsal sanatçı artık izleyici üzerinde figüratif bir tema dayatmıyor, ancak kendi hayal gücüyle ve onun aldığı imgelerle kendisini yaratma pozisyonuna sokmasına izin veriyor." Uzamsal çevreyi değişimin başlatılması için bariz bir çözüm olarak gören sanatçı: 
"Sanatta hâlâ taş ve renk kullanmakla hiçbir evrim olmaz, 1şık, televizyon ve projeksiyonla yeni bir sanat inşa etmek mümkün olacaktır," sözleri ile malzeme kullanımında teknolojinin bize sunduğu geniş yelpazeden yararlanılması gerektiğini vurgular (Pasini, 2008).

Bazen onun enstalasyonlarında büyük bir boşlukta ince bir ip gibi duran neon 1şı̆̆1, izleyiciyi ruhsal bir atmosfere sürüklerken bazen de Enerji Kaynağı adlı enstalasyonunda olduğu gibi, zemine yakın yatay düzlemde dizilmiş onlarca neon 1şı̆̆1, bir ağ gibi tavan ve zemin arasında yeni bir katman yaratır. Boşluk, izleyicinin varlığı ile kendi doluluğunu yaratır. Bu enstalasyonlar, renklendirilmiş boşluk ve neon 1şıkları ile yaratılmış alan, izleyiciyi hareketli resimsel bir ortama ve farklı bir deneyime davet eder.

\subsection{Dan Flavin}

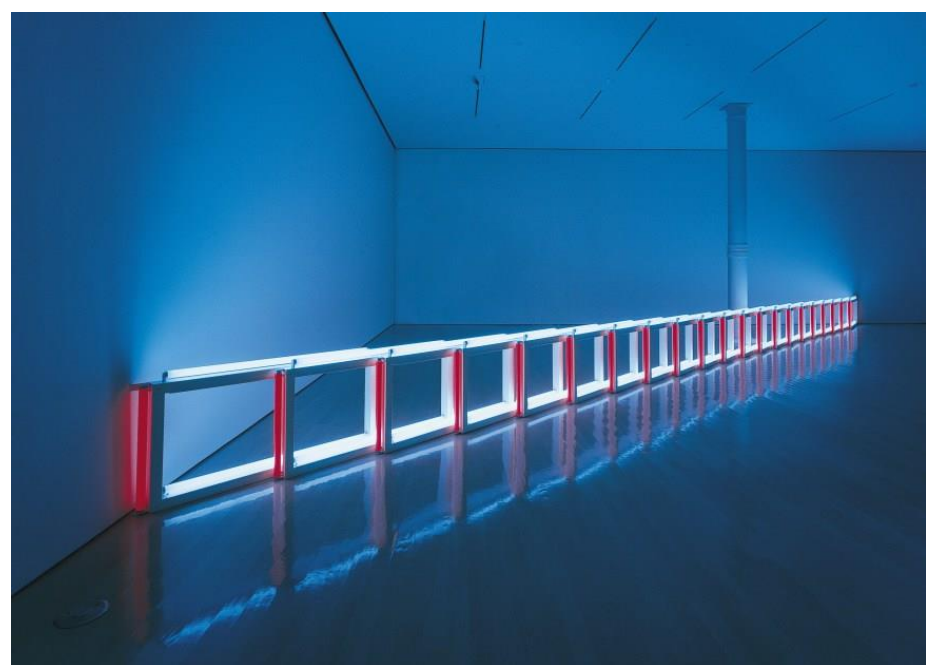

Resim 4. Dan Flavin, Kırmızı, Mavi Floresan Işığı Mavinin Yapay Bariyeri (Flavin Starbuck Judd'a), 1968, Mavi ve kırmızı floresan ışığı

1960’lı yılların başından itibaren mekânın sınırlarını neon lambaları ile belirlediği çalışmaları ile tanınan Dan Flavin'in yapıtlarının temeli Fineberg'e göre (2014:287-288) Katolik yetiştirilme tarzının ruhsallığı ile mücadelesine uzanır. 1961-62'de yalın renk düzlemlerini ve basit geometrik formları elektrik lambaları ile birleştirdiği 'İkonlar' serisi daha sonraları sadece floresan 1şı̆̆ını kullanarak gerçekleştireceği işlerin öncüsüdür.

1966 yılında Piet Mondrian'a adadığı yeşil enstalasyonla benzer olan bu enstalasyon, Donald Judd'un oğluna adanmıştır. Onun adı iki sanatçı arasındaki yakın dostluğa da işaret etmektedir. Birçok çalışmasını sanatçı arkadaşlarına ya da belirli kişilere adaması, minimalist anlayıştaki bu işlerine farklı bir boyut kazandırır. Flavin’in koridorları galeri alanındaki izleyicinin hareket alanını sınırlar. Bazen her iki taraftan yaklaşmaya olanak sağlayan bazen burada olduğu gibi mekânın bir köşesinden diğer köşesine çapraz olarak sıralanan 1şık koridorları arasında belirli aralıklar bırakarak ışığın görünürlüğünü arttırır veya renklerin karışımına izin verir (Mann, t.y.). Bazen floresan lambaları arasında bıraktığı boşluk bazen floresan lambalarının kapladığı alandan arda kalan boşluk bazen ise her ikisini de kapsayan 
boşluktan yayılan 1şık, kendi özel alanını oluşturur. Bu 1şıklar, mimari alanı desteklemenin yanı sıra orayı yeniden yapılandırır. Artık 1şık ve mekân etkileşim içerisindedir.

Floresan tüplerini düzenlerken formdan çok uzam olarak heykel düşüncesini araştırır. Iş1k, özellikle her bir parçayı, konumuyla karşılıklı bağımlı hale getirerek uzamı açıkça belirtiyor. Işığın sınırsızlığı onun için yücelik ile özdeştir ve aynı zamanda ruhsallıkla bağlantılıdır. Endüstriyel ile aşkın olanı alışılmışın dışında bir kaynaşma ile sunar; kendisinin deyimiyle "modern bir teknolojik fetiş" haline getirir (Fineberg, 2014, s. 288).

\subsection{Bruce Nauman}

Bruce Nauman ise neon 1ş1klarını, sanatın toplumdaki rolü ve işlevi üzerine söylemlerini gerçekleştirilebileceği etkileyici bir araç olarak görür.

Neon 1şıkları ile birçok çalışması bulunan Nauman'ın Keman, Şiddet, Sessizlik adlı işi, resmin adında da geçen kelimelerin iki defa tekrarlanmasından oluşur. Her kelimenin biri soldan sağa, diğeri sağdan sola doğrudur. Altı kelime üçgen şeklini oluşturur. 'Sessizlik', sözcükleri yatay düzlemdedir ve iki kelime üst üste aynı düzlemde bindirildiği için biri zor okunur. Üçgenin yan kenarları 'şiddet' ve 'keman' kelimelerinden oluşur. Her kelime, kırmızı, sarı ve pembe tek bir renkte görülmekte ve neondan bir uğultu sesi duyulmaktadır. Hepsi aydınlanmadan önce kelimeler belirli bir döngüde aydınlanmaya başlar. Döngü, 'sessizlik' ile başlar, sonra soldaki 'şiddet', ardından soldaki 'keman', tekrar 'sessizlik', sonra 'şiddet' ve en son sağdaki 'keman' kelimesi aydınlanır.

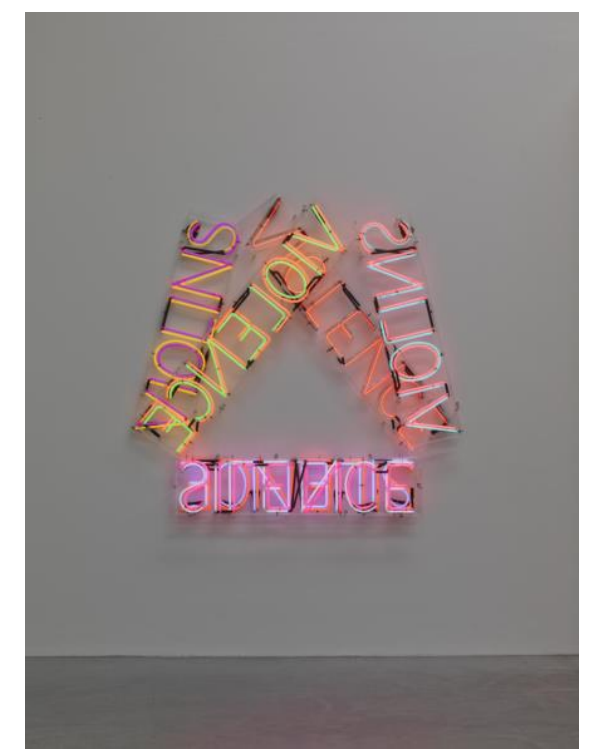

Resim 5. Bruce Nauman, Keman, Siddet, Sessizlik, 1981-82,

Saydam cam ve asma aparatı ile neon hortumlar1, 157,8x166,1x15,2 cm

Nauman'ın neon 1şıklarını kullanması Davis California Üniversitesi'ndeki öğrencilik yıllarına dayanır. Yağlıboyaya batırdığı ya da üzerini boyadığı bu neon çalışmalarını nedense yok etmeyi tercih etmiştir (Akt. Musiol, 2013).

Enstalasyona tekrar dönecek olursak; yazının kullanıldığı diğer neon çalışmalarında olduğu gibi bu türden çalışmalar galeri ya da müze mekânına girdikleri andan itibaren ticari bir tabela olmaktan çıkar. Kelimelerin üst üste binmesi ve üçgen formunu oluşturacak şekilde dizilimi onların soldan sağa okunmalarını güçleştirir. Onların kendi aralarında ürettikleri semantik 
ilişki ve görsel şablon, kelimelerin kendi önemliliğini vurgular. 'Violence' (şiddet) kelimesi, 'violins' (keman) kelimesinin ilk dört ve 'silence' (sessizlik) kelimesinin son beş harfini içerir. Kelimeler kendi içlerinde bir durum ve ses ifadesine sahiptirler. Küratör Joseph D.Ketner: "Keman sessizliğinin şiddet tarafından susturulan ve sessizlik tarafından bozulan saf müzikal bir ses yarattığını," dile getirir. Sanatçı burada adeta görsel formda sesli bir şiir yaratır (Akt. Musiol, 2013).

Herhangi bir müzikalite duygusu bir çalgı aletine referans yoluyla, şiddetin ima edilmesiyle karmaşıklaşan karşıt sessizlik fikri tarafından etkisiz hale getirilir. Kelimelerin tekrarı ve katmanlaşması, görünüşte önemsiz bir mesajı iletir. Ancak 'sessizlik' kelimesinin okunaksız çifte sunumu, kelimeyi ve anlamı susturmak istercesine üçgenin tabanına yerleştirilmiştir. Richardson, Nauman'ın neonlarda izleyiciyi tepki vermek üzere kışkırttığını ve neonlardaki dilin çoğunlukla bölük pörçük ya da kavgacı bir tonda olduğunu dile getirir (Akt. Musiol, 2013). Aslında sanatçı, neon 1şıklarının 1şıltılı yapısının galeri ya da müze mekânına taşındığında nasıl çatışmacı bir potansiyele bürünebileceğini fark etmiş ve bunu da başarılı bir şekilde sanatsal deneyimlerine aktarmıştır.

\subsection{Sarkis Zabunyan}

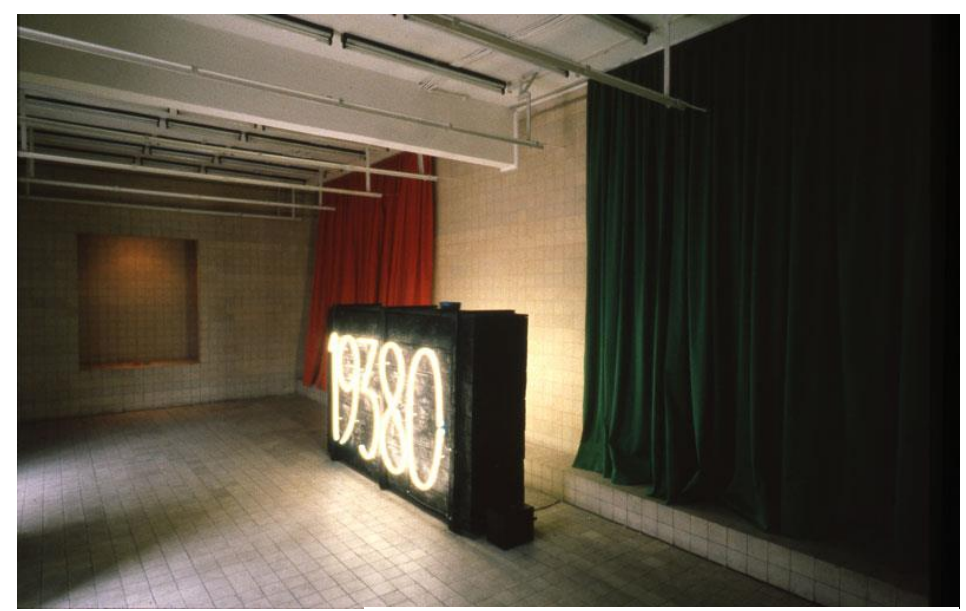

Resim 6. Sarkis Zabunyan, 19380 - 19930, Ayrınt1, 1993, Enstalasyon, Maçka Sanat Galerisi, İstanbul

Sarkis Zabunyan'ın büyük ahşap bir sandığın ön yüzüne neon 1ş1klarıyla 19380, arka yüzüne ise 19930 yazdığı enstalasyondaki ön yüzdeki rakamlar 1938 sanatçının doğumuna; arka yüzeydeki ise 1993 eserin sergilenme tarihine vurguna bulunur. Işıklar adeta nefes alıp verme gibi yanıp sönerken, sandık ise yer değiştirmeye, göçebeliğe, yeni başlangıçlara ilişkin anıları tazeler. Sarkis, sandığın soluna kırmızı, sağına ise odalara geçişi de engelleyen yeşil bir perde yerleştirir. Kırmızı perdenin arkasından sıcak havanın üflenmesi, perdenin dalgalanmasına neden olmaktadır. Sandığın üzerine dönen bir mekanizma, onun da üzerine kırmızı ve yeşile boyanmış suluboya kâğıdından yapılmış iki küçük evin yüzdüğü mavi bir kâse yerleştirilmiştir. Ayrıca sandığın sol tarafındaki duvara, su dolu iki bardağın içine yine biri 
kırmızı diğeri yeşile boyanmış ev formunda kâğıtlar, üstten aydınlatılan ışığın altına renklerini yitirmek üzere birakılmışlardır (Akt. Atakan, 2008, s.98).

Bellek, tarih, zaman gibi kavramlar Sarkis için oldukça önemlidir. Bu enstalasyonda da bu kavramları görmek mümkündür. Bu enstalasyonun yer aldığı serginin kataloğuna yazdığ1 metinde Elvan Zabunyan, Sarkis'in bu işi ile Piero della Francesca'nın Hamile Meryem adlı duvar resmi arasında bağlantı kurar:

“...Burada Meryem Ana, bir çadırın eteklerini kaldıran iki melek tarafindan gösterilir. Soldaki melek yeşil giysiler içindedir, kanatları ve çizmeleri kırmızıdır. Sağdaki melek ise kırmızı giysilidir, kanatları ve çizmeleri yeşildir. Azizlerin başlarındaki halelerin saydamlığını daha iyi belirtebilmek için üç kişinin önünde durduğu duvarı bu halelere de işler. 19930'un galerinin duvar karoların aydınlatmasında da aynı saydamlık imgesini görürüz. İçinde bulunduğumuz mekânın gerçekliği bize böyle anımsatılırken, tüm sergi Sarkis'in teatral mekânı belirtmek için gerçek perdeleri ilk kez kullandığı bir sahneye doğru yönelir" (Akt. Eyigör, 2013).

\subsection{Massimo Uberti}

Işık, yapıta kendi varlığı ile katıldığı anda, sembolik değerini sınırlı bir yüzeyden bambaşka bir düzleme genişletir. Neon 1şıkları ile yapılan eserlerde 1şık, gerçek alana hâkimdir ve sanatçı artık boyanın renk değerleri ile bir atmosfer yaratmak zorunda değildir. Işık kaynağı sadece nesneyi, yazıyı, yapıyı aydınlatmaz aynı zamanda bir iletissim alanı da yaratır. İşte Massimo Uberti'nin 1ş1klı heykelleri de böyledir. Sanatçı mekân içine sandalye, masa, merdiven, dış duvarları ile yeni bir mekân çizer. Neon 1şıkları ve transformatörleri kullanarak, onun çizdiği minimal alana giriş için bir kap1, bu yaratılmış alandan reel mekâna açılan penceresi ile çizilen yap1, içinde herkesin evinde bulunabilecek gündelik nesneleri barındırır.

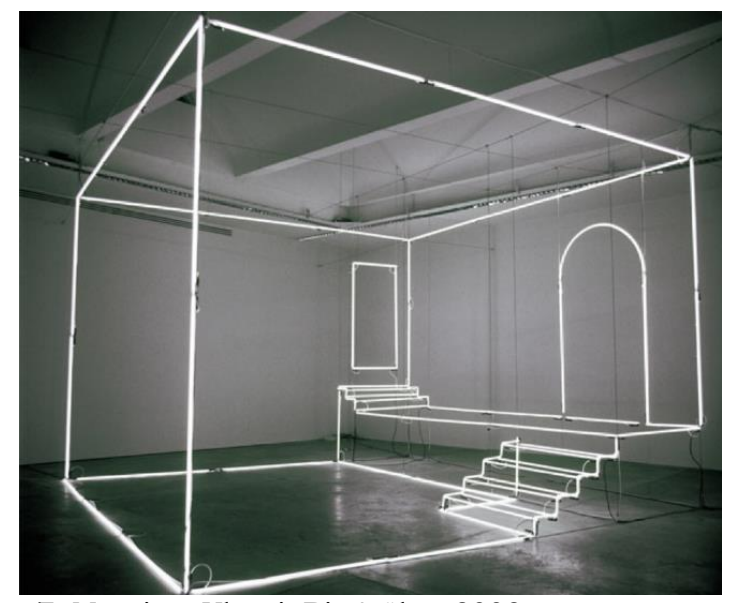

Resim 7. Massimo Uberti, Bir Atölye, 2003

Onun eserleri 1şık olmadığında görünmezler, 1şıksızlık onları özlerinden ve şiirsel güçlerinden yoksun bırakır. Kendisinin de ifade ettiği gibi: "Doğrudan hem uzaklığı hem de tüm engelleri kaldırma seçeneğinin ortasında 1şık, temel unsur haline gelir - eserin kendisi-. " Uberti, 1şığın bir yaşam kaynağı olduğu rolünü sanatta güçlendirenlerdendir. Çalışmalarında 1şık, yalnızca eseri ortaya çıkarmakla kalmaz aynı zamanda onun maddi bir görünüşe dönüşmesi, kavramsal tutarlılığıyla bir araya getirilmesi, boşluğun dışına bir geçiş sunması bakımından da önemlidir. 
O, izleyicinin sevilen, sonsuz, gerekli veya farklı anlamlarda gördüğü alanda deneyim kazanması için fırsat sunar. Hazırlanmış bu alan, izleyicinin onun bir parçası olması ile anlam kazanacaktır. Bir Atölye geçmişin tasarım çizimi ile bağlantılı ikonografik temalara da bir dönüştür. Çünkü mekânda çizgiler vardır. Bunlar daha abartısız daha detaylı hale gelir sanki yapı, mekâna çizim sayesinde yansıtılmış gibidir (Mazzini, t.y.). Uberti 1şıklı mimari heykellerine ilişkin şöyle der: "Iş1k yapıları yaratmaktan hoşlanıyorum. Romantik sakinlere yer inşa etmek için neon tüplerini kullanıyorum, hayal etmeye izin veren rüyaya benzer mekânlar yaratmayı deniyorum"( Jungbauer, 2015).

\subsection{Joseph Kosuth}

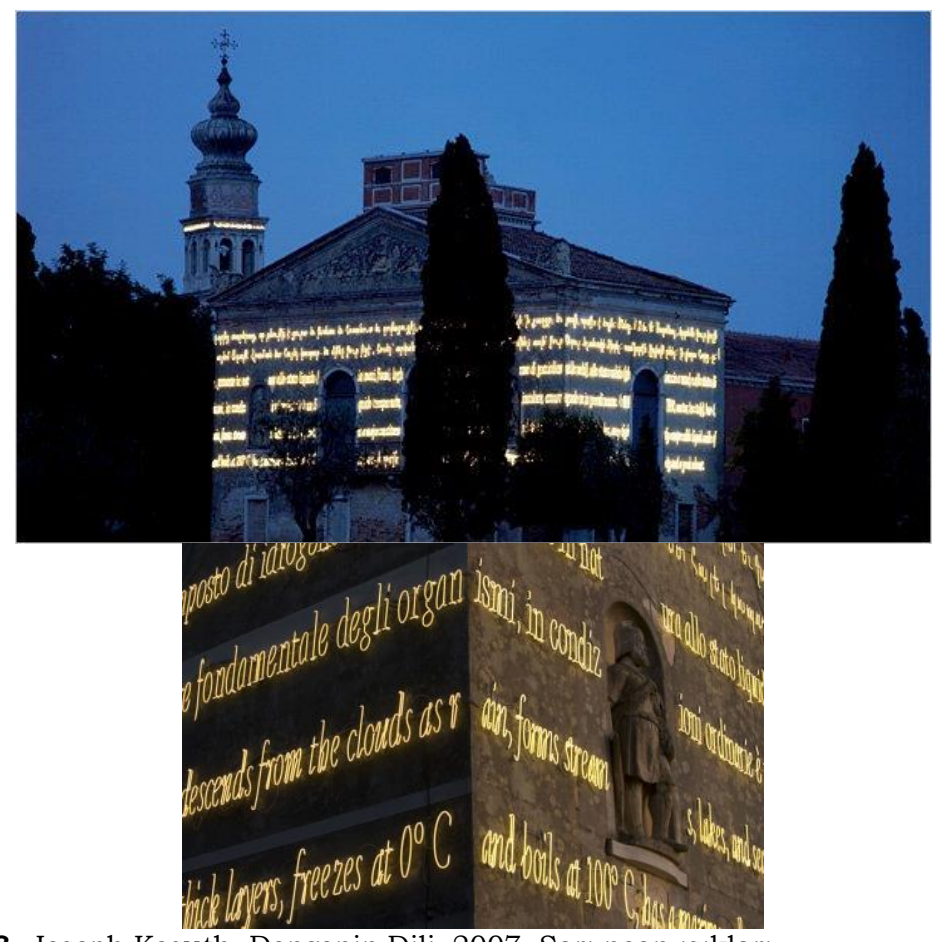

Resim 8. Joseph Kosuth, Dengenin Dili, 2007, Sarı neon 1şıkları,

San Lazzaro Adası, Ermeni Mekhitarian Manastırı, 52.Uluslararası Venedik Bienali

Nesneler ve onları tanımlamak için kullanılan sözcükler arasındaki ilişkiye, dil ve içeriğin rolüne değinen Joseph Kosuth, büyük boyutlu yazı ve mekânı bütünleştirdiği bir enstalasyon ile karşımıza çıkıyor. Sanatçı, San Lazzaro Adası'nda yer alan Ermeni Mekhitarian Manastırı'nın kuzeybatı duvarının tamamını, çan kulesi ve adanın kıyısındaki duvarı Ermenice, İtalyanca ve İngilizce metinlerle kaplamıştır. Sarı neon 1şıklarla yazılı olan bu metinler, 'Su' temasına ilişkin sanatçının derinlemesine analizlerini içerir. Kavramsal sanatın en önemli temsilcilerinden biri olan Kosuth, kelimelerin etimolojisi ile oynamaktan oldukça zevk alır. Suyun tarihsel kullanımı ve dilsel gelişimi arasındaki ilişki, manastırın duvarlarına aktarılır. Ermeni kültüründen emanet bir manastır üzerindeki bu metinleri neden sarı neonlarla yazdığını sanatçı şöyle açıklar: 
"Sarı neon ışı̆̆ı, manastırın kuruluşunda sarının sembolik anlamından dolayı, erdem, akıl, saygınlık ve ihtişamı ifade ettiği için seçtim.”

Dengenin Dili adlı bu enstalasyon, manastırın anıtsal mimarisine, 1ş1tılı bir görkem ekleyerek, onun uluslararası kültür içindeki yerini de vurgular. Bu enstalasyonda suyun dilsel tanımlarına yer verilmiştir. Bu tanımlar, Abbott Mekhitar tarafından derlenen Ermeni sözlüğünden alınmıştır. Sanatçı bu tanımlamalara kendi oyuncul dilini yerleştirir. Temanın su kavramı üzerine kurulmuş olması, bu enstalasyonda suyun önemli olduğunu vurgular. Hem çevrelediği ada hem Venedik için önemli olan suyun, bu anlamda tarihsel öneminin yanı sıra, özellikle son yıllarda küresel çevre tartışmalarında oldukça sık değinilen bir konu olduğunu düşünürsek bunun; çok yönlü, referanslar ve ilişkiler ağ1 ile bütünleşen bir enstalasyon olduğunu söylemek yanlış olmasa gerek (Kosuth, 2009).

\subsection{Iván Navarro}

Minimalizm’in, özellikle de Dan Flavin'in floresan 1ş1k heykellerinin görsel dilini kullanan Iván Navarro, 'Bu Toprak Sizin Toprağınız' (This Land is Your Land) başlıklı üç ahşap su tankından oluşan enstalasyonu, Madison Square Park’ta sergiler. Ziyaretçiler, su tanklarının altına geçtiklerinde kulelerden birinde neon 1şıkları ile 'me/we' (ben/biz), diğerinde 'bed' (yatak) yazısı ve üçüncüsünde de neon 1şıklarından oluşturulmuş bir merdiven göreceklerdir. İçeride panellerin ayna ile düzenlenmesi ile her bir kelime ya da görüntü, izleyiciye göğe doğru yükseliyormuş ya da sonsuzluk hissi vermektedir. Bu kelimeler, göçün siyasi ve kişisel tecrübesine yöneliktir.

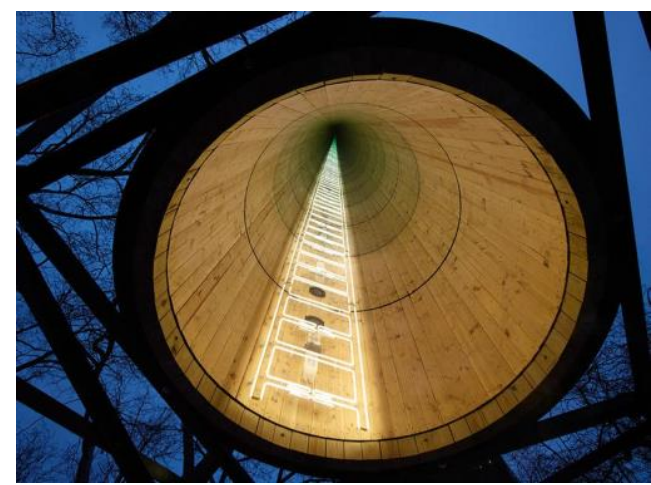

Resim 9. Iván Navarro, Merdiven (Su Kulesi), 2014, Neon, ahşap, boyalı çelik, alüminyum, ayna, tek yön aynası ve elektrik enerjisi, 480,1x267x267 cm, Madison Square Park, New York

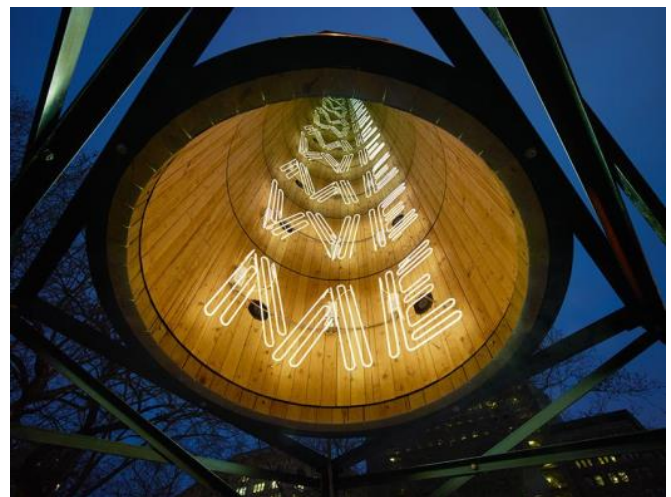

Resim 10. Iván Navarro, Ben/Biz (Su Kulesi), 2014, Neon, ahșap, boyalı çelik, alüminyum, ayna, tek yön aynası ve elektrik enerjisi, 480,1x267x267 cm, Madison Square Park, New York 


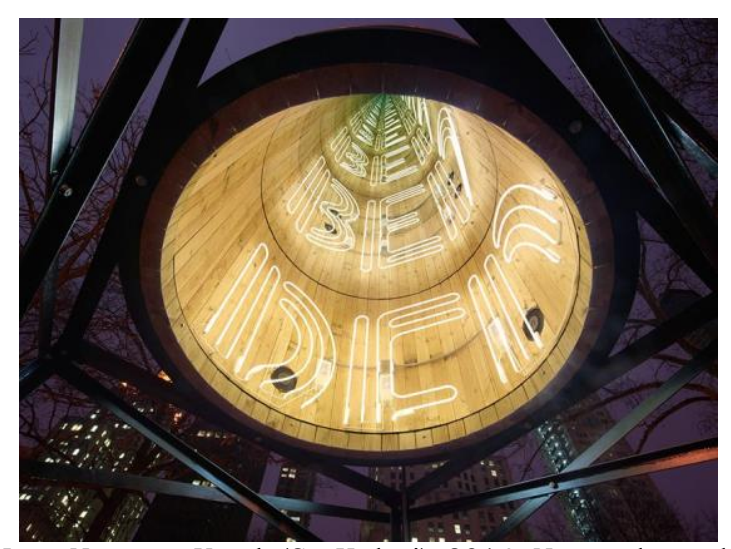

Resim 11. Iván Navarro, Yatak (Su Kulesi), 2014, Neon, ahşap, boyalı çelik, alüminyum, ayna, tek yön aynas1 ve elektrik enerjisi, 480,1x267x267 cm, Madison Square Park, New York

Sergi adını, hem bir Amerikan marşı olan hem de göçmen nüfusa adanan özgürlüklere bir ses olan 1940'lardaki bir halk müziği şarkısından alır. Navarro su deposu fikrini sevdiğini şöyle dile getirir: "Su haznesi fikrini seviyorum. Bu basit ve zamansız ahşap yapı su içermektedir, en ilkel ve en temel kaynaktır, insanın sağlı̆̆ının özü ve tüm insanlığın paylaştığı temel koşulların hatırlatıcısıdır. Hayatta kalabilmek için suyumuzu garanti altına almalıyız. Bu anlamda su depoları ilkel bilginin konteynerleridir. Formları ve malzemeleri eşit derecede arkaiktir: bunlar, ahşaptan yapılmış, konik çatılara sahip basit dairesel kulübe şeklindedir. Daha az belirgin ama yine de önemli olan, yüksek konumlarından dolayı gözetleme kulelerine verdikleri referans. Onlar iyi özelliklere sahip nesneler olmasına rağmen, sessizce bizi çevreleyen, aşağıdaki şehri inceleyen bir anlam taşıyor. Bu su kuleleri, kent manzarasına hakim olan büyük binalarda üstlerindeki süslemeler olarak metaforik anlamda işlev görürler (Azzarello, 2014).

Brooke Kamin Rapaport ise Navarro'nun bu enstalasyonda ve birçok çalışmasında çocukluğunda Şili'deki acımasız Pinochet rejimi sırasında yaşadıklarını ve belleğini kullandığını ve bunu da bu çalışmasında Amerikan yaşamının özgürlükleri üzerine yansıttığını ifade eder. Rapaport, bu enstalasyonu, demokrasi, toplumsal yap1 ve zulmün ayn1 anda nasıl ifade edilebileceğine ilişkin konuları ele aldığı için önemli bulmakta. Rapaport, Navarro'nun su kulelerine ilişkin: "Ahşap su depoları New York'un çatılarının her yerinde görülürken, sanatçı onları bugünkü kritik meselelerin bir taşıyıcısı olarak ya da heykelin nesne olarak nasıl işlev gösterdiğini kapsamlı bir içerikle yüklüyor,” sözleri ile bilinen bir nesnenin, kendi işlevselliğinin dışında nasıl başarılı bir biçimde yeni anlamlarla sunulduğunu vurguluyor (Madison Square Park Conservancy Programs, 2014). 


\subsection{Olafur Eliasson}

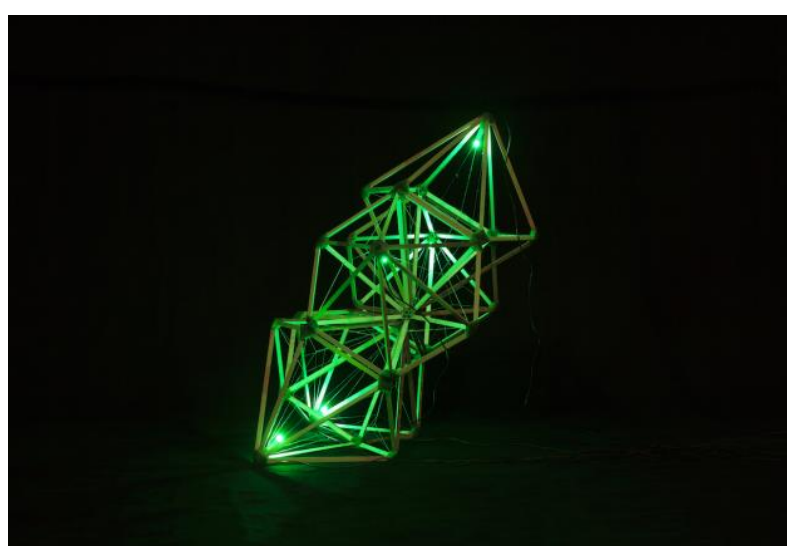

Resim 12. Olafur Eliasson, Yeşil Işık, 2016, Ahşap,

Geri dönüştürülmüş yoğurt bardakları, kullanılmış plastik torbalar, geri dönüştürülmüş naylon, LED (yeşil), $35 \times 35 \times 35 \mathrm{~cm}$.,

Fotoğraf: Olafur Eliasson'un Stüdyosu

Mekân, mesafe, renk ve 1şıktan oluşan çalışmalarıyla tanınan Olafur Eliasson'un Yeşil Işık adlı çalışması, işbirlikçi bir çalışmadır. Viyana Augarten'deki bir atölye bu çalışmanın oluşturulması için mülteci, göçmen ve üniversite öğrencilerini davet eder. Atölyede Eliasson tarafından tasarlanan yeşil LED 1şıklı lamba çalışmasının yanı sıra, seminer, gösteri gibi diğer sanatsal faaliyetlerin de olduğu kapsamlı bir işbirliği söz konusudur. Bu çalışmanın temeli Avusturya'nın son yıllarda yaşanan mülteci krizine yönelik tavrıdır. Göçmenlere kırmızı 1şık yakan Avusturya'nın ülke sınırında denetimlerin arttırılacağını duyurması, sanatçıyı böyle bir çalışma yapmaya iter. Aslında bu, çağdaş sanat aracılığı veya onun potansiyeli ile sivil dönüşüm sürecini başlatma üzerine bir deneyimdir. Burada sanatçının sözlerine yer vermek çalışma açısından açıklayıcı olacaktır:

"Hem kendi ülkelerindeki sorunlardan, istikrarsızlıktan kaçan kişilere hem de Viyana sakinlerine hitap eden bir karşılama eylemidir. Eğlenceli yaratıcı süreçte birlikte çalışarak katılımcılar modüler bir 1şık oluştururlar ve farklılığın yalnızca kabul edilmediği aynı zamanda benimsendiği ortak bir ortam oluştururlar. Umuyorum, Yeşil Işık, Avrupa ve dünyadaki mevcut mülteci krizinden kaynaklanan zorlukların ve sorumlulukların bir kısmına 1şık tutacak" (Artist web site, t.y.).

\subsection{Maurizio Nannucci}

Maurizio Nannucci ise sanat eserini estetik kabuğundan çıkararak, mümkün olduğunca deneyimsel bir role büründürür. Mimari alanda, renk-1şık-yazı ile bütünleştirdiği çalışmalarında, imajın sınırlarını aşarak, her izleyicide farklı zihinsel görüntülerin oluşmasına olanak tanır. Renk ve 1şık ile etkili hale gelen metin, mimari yapı ile birlikte uyarıcı bir etkiye sahip olur. Bu etki, göreceli zihinsel bir görüntünün oluşumu ile sonlanır. Bu çalışmalarda, neonun parlak, 1ş1tılı etkisi ve renkle birlikte kullanımı yadsınamaz bir öneme sahiptir. Nannucci neon 1şı̆̆ının: "Gerçeklikle etkileşim ve algılama anlayışında yeni perspektifler açarken, şekillendirmeye ya da mekânı temsilin sıfır derecesine oldukça yakın olan kavramlara ve duyumlara dönüştürmesine izin verdiğini," ifade eder (Spirou, 2015). 


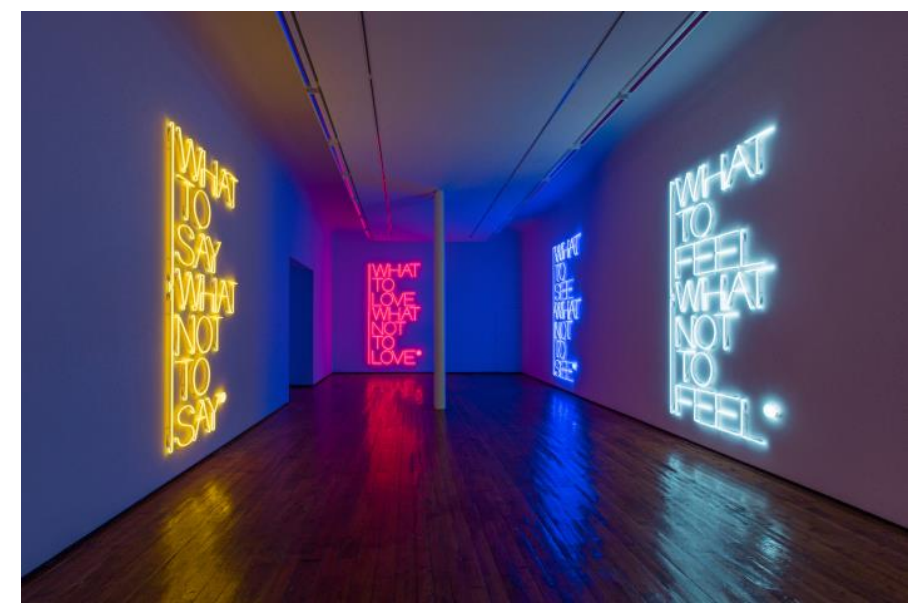

Resim 13. Maurizio Nannucci, Görülecek Şey, Görülmeyecek Şey, 2017, Enstalasyon, Fumagalli Galerisi, Milano

Sanatçının Fumagalli Galerisi'nde sergilenen Görülecek Şey, Görülmeyecek Şey adlı bu çalışması, farklı renklerde neon 1şıklarla yazılmış olumlu ve olumsuz ifadelerin tekrarlanmasından oluşur. İki karşıt kutup arasındaki bu sıkı diyalektik ile Nannucci, kendiliğinden sonuçlandırılmış bir eylemin etkililiğinde, mutlak bir doğrulamada değil, onaylama ve inkâr, yanıtın imkânsızlığı ve talebin performatifliği arasında üretken bir alanda gerçekliğin anlamsal bileşenini devamlı durdurur. Görülecek, görülmeyecek şey, söylenecek, söylenmeyecek şey... İnsanının toplumdaki ikili ilişkilerindeki durumunu, kendisi ya da başkaları ile yansıtan bir gerginlikte soruyor. Her gün ortaya çıkan insanı seçim yapmaya zorlayan bir durum, kararlarımızı nasıl yönlendireceğimiz üzerine bir sorgulama. Anlam, anlaşılmaz ya da çözümlenmemiştir. Ama Nannucci'nin amacı çözüm sunmak değildir, bizi kuşatan işaretleri yorumlamak, farklı okuma olasılıklarını sunmak ve anlamlandırmaktır. Nannucci kelimelere sembolik bir dil katar. Kendisi bunu şöyle açıklıyor: "İmajın, zihinsel bir görüntüye, göz alıcı bir manzara ya da sanal bir görüntüye, bir kelime, ses ya da koku ile çağrışım yapan görsel ya da göreceli bir görüntüye dönüşerek temsilin sınırlarını aştığına inanıyorum." Görsel medyayı dile ve yazıya indirgeyerek, çalışma ve izleyici arasında takası aktifleştirerek, yeni deneyimlere sürükleyerek, duyusal algı uyandırmaktadır. Kişinin kendisi, duyguları, kavramsal yansımalar ve çevresi arasında derinlikli bir ilişkiye yol açar (Galleria Fumagalli, Exhibition Catalogue, 2017).

\section{SONUÇ}

Resimde derinliği ve hacmi daha belirgin hale getirmeye yarayan 1şık, 20.yüzyılın ilk çeyreğinden sonra sadece resimle sınırlı kalmaz. Mimari ve heykel gibi farklı disiplinlere de yayılır. Öncesinde onu doğrudan göremediğimiz ya da etkileşime geçemediğimiz 1şık, artık müze ya da galeri mekânının duvarında sergilenen bir resimde gördüğümüz pasiflikte değildir. Işık 
yapıta varlığı ile katıldığını biz izleyiciye gösterir. Alana hâkimiyeti söz konusudur. Boyanın renk değerleri ile yaratılan atmosfer, neon 1şı̆̆ının diğer 1şıklarla birleşmesi ile reel mekânlarda bizi atmosferi yaşayan, anı deneyimleyen, yapıtı anlamlandıran konumuna getirir. Burada sanatçının hedeflediği şey, sadece metni, nesneyi ya da yapıyı aydınlatmak değildir. Aynı zamanda bir iletişim alanı yaratmak için bu büyülü, parlak, 1şıldayan nesneden yararlanır.

Sonuç olarak, fotoğraftan heykele, mimariye, enstalasyonlara çok kapsamlı bir kullanım alanına sahip 1 şık, bazen resim veya heykelin malzeme kullanımının dışına çıkarak formun dış hatlarını çizerken, bazen ultraviolet 1şıkları birlikteliği ile mekânı büyülü bir atmosfere dönüştürür. Bazen bildiğimiz ya da yaşam alanlarımızda kullandığımız 1şık kaynağı formunun tekrarlanması ile mekânın içinde kendine bir alan yontar. Bazen günlük hayatımızda kullandığımız basit sözcüklerin galeri, müze, tarihi mekân ya da şehrin içinde herhangi bir alanda karşımıza parıldayarak çıkıp, bizleri düşünmeye, o kelimelerin bizdeki anlamını ya da bindirildikleri yüzey ile ilişkilerini sorgulamaya iter. Sözcüklerden imajlar oluşturmamıza katkı sağlarlar. Neon 1şıkları, sanatta malzeme çeşitliliğinin en güzel örnekleri arasında yer almanın yanı sıra, birçok anlamı iletebilmek, izleyiciye deneyim yaşatabilmek adına da oldukça etkilidir.

\section{KAYNAKÇA}

Artist web site. (t.y.). Green light. Erişim adresi: http:/ /www.olafureliasson.net/archive/artwork/WEK109681/green-light\#slideshow

Atakan, N. (2008). Sanatta alternatif arayışlar. İzmir: Karakalem Kitabevi.

Azzarello, N. (2014, 26 Şubat). Ivan Navarro places infinite neons within water tower sculptures. Designboom. Erişim adresi: https://www.designboom.com/art/ivan-navarro-placesinfinite-neons-within-water-tower-sculptures-02-26-2014/

Eyigör, F. (2013, 7 Şubat). Sarkis'in 19380-19930'undan 2009'a Kalanlar. Erişim adresi: https:/ / feyigor-arttick.blogspot.com.tr/2013/02/sarkisin-19380-19930undan2009a.html?view=magazine

Farthing, S. (2012). Sanatın tüm öyküsü. (G.Aldoğan ve F.Candil Çulcu, Çev.). İstanbul: Hayalperest Yayınevi.

Fineberg, J. (2014). 1940’tan günümüze sanat: varlık stratejileri. (G.E.Y1lmaz, Çev.). İzmir: Karakalem Kitabevi Yayınları.

Galleria Fumagalli Exhibition Catalogue. (2017). Maurizio Nannucci: what to see what not to see, $\quad$ May, 3 - $\quad$ July, $22 \quad 2017 . \quad$ Erişim adresi: http://galleriafumagalli.com/en/mostra/what-to-see-what-not-to-see/

Jungbauer, J. (2015, 7 Aralık). Minimal light installations by Massimo Uberti, Ignant. Erişim adresi: https://www.ignant.com/2015/12/07/minimal-light-installations-by-massimouberti/

Kawamura Memorical Dic Museum of Art. (t.y.). Past exhibitions: Moholy-Nagy in motion. Erişim adresi: http://kawamura-museum.dic.co.jp/en/exhibition/201111_moholy.html

Kosuth, J. (2009). Art, Joseph Kosuth: the language of equilibrium, description, Fiona Biggiero (curator). Electa. Erişim adresi: http://www.electa.it/en/product/joseph-kosuth-illinguaggio-dellequilibrio/

Madison Square Park Conservancy Programs. (2014). Iván Navarro, February 20, 2014-April 20, 2014. Erişim adresi: https://www.madisonsquarepark.org/view-do/calendar/mad-sqart-ivan-navarro

Mann, T. (t.y.). Dan Flavin: an artificial barrier of blue, red and blue flurescent light to Flavin Starbuck Judd. Gughenheim collection online. Erişim adresi: https://www.guggenheim.org/artwork/1308 
Mazzini, M. (t.y.). Massimo Uberti, text. Erişim adresi: http://www.massimouberti.it/text/

Moholy-Nagy, L. (t.y.). Light-space-modulator. Erişim adresi: http:/ /www.medienkunstnetz.de/works/licht-raum-modulator/

Musiol, A. (2013, Şubat). Bruce Nauman: violins violence silence, 1981-2. Tate. Erişim adresi: http://www.tate.org.uk/art/artworks/nauman-violins-violence-silence-al00223

Pasini, F. (2008, 1 Eylül). It is not a lasso, an arabesque, nor a piece of spaghetti. Tate Etc., 14. Erişim adresi: http://www.tate.org.uk/context-comment/articles/it-not-lasso-arabesquenor-piece-spaghetti

Ribbat, C. (2013). Flickering light: a history of neon. London: Reaktion Books.

Spirou, K. (2015, 26 Temmuz). The essence behind the light: Maurizio Nannucci at MAXXI. Yatzer. Erişim adresi: https://www.yatzer.com/maurizio-nannucci-maxxi

\section{Resim Listesi}

Resim 1. László Moholy-Nagy. Iş1k-Mekân modülatörü. Erişim adresi: https://www.dailyicon.net/category/life/art/page/12/

Resim 2. László Moholy-Nagy. Neon 1şılkları Chicago. Erişim adresi: https: / /icpbardmfa.wordpress.com/2015/02/22/

Resim 3. Lucio Fontana. Enerji kaynakları. Erişim adresi: http://artresearchmap.com/exhibitions/lucio-fontana-ambientienvironments /

Resim 4. Dan Flavin. Kırmızı, Mavi floresan 1şı̆̆ mavinin yapay bariyeri (Flavin Starbuck Judd'a). Erişim adresi: https://www.guggenheim.org/artwork/1308

Resim 5. Bruce Nauman. Keman, şiddet, sessizlik. Erişim adresi: http://www.tate.org.uk/art/artworks/nauman-violins-violence-silence-al00223

Resim 6. Sarkis Zabunyan. 19380 - 19930. Erişim adresi: http://www.sarkis.fr/1992-19380$19930 /$

Resim 7. Massimo Uberti. Bir atölye. Erişim adresi: http://www.massimouberti.it/

Resim 8. Joseph Kosuth. Dengenin dili. Erişim adresi: https: / mobile.nytimes.com/images / 1194719877450/2007/11/18/travel/tmagazine/ 14 well-collectors-t.html,_erişim tarihi: 1 Mart 2018, http://www.neonlauro.it/

Resim 9. Iván Navarro. Merdiven (su kulesi). Erişim adresi: http://www.disup.com/ivannavarro-this-land-is-your-land/

Resim 10. Iván Navarro. Ben/Biz (su kulesi). Erişim adresi: http://www.disup.com/ivannavarro-this-land-is-your-land/

Resim 11. Iván Navarro. Yatak (su kulesi). Erişim adresi: http://www.disup.com/ivan-navarrothis-land-is-your-land/

Resim 12. Olafur Eliasson. Yeşil 1ş1k. Erişim adresi: http://www.olafureliasson.net/archive/artwork/WEK109681/green-light\#slideshow

Resim 13. Maurizio Nannucci. What to see What not to see. Erişim adresi: http://galleriafumagalli.com/en/mostra/what-to-see-what-not-to-see/ 